\title{
Effects of Supplied Nitrogen Form and Quantity on Growth and Postharvest Quality of Ranunculus asiaticus Flowers
}

\author{
Nirit Bernstein ${ }^{1}$ and Marina Ioffe
}

Institute of Soil Water and Environmental Science. ARO, The Volcani Center, POB 6, Bet Dagan, 50250 Israel

Moshe Bruner, Yair Nishri, and Gideon Luria,
Extension Service, Ministry of Agriculture, Israel

Irit Dori and Eli Matan

Havat Habsor, R\&D South, MP Negev, 4, 85400

Sonia Philosoph-Hadas

Department of Postharvest Science of Fresh Produce, ARO, The Volcani Center, Bet Dagan 50250 Israel

\section{Nakdimon Umiel and Amir Hagiladi \\ Institute of Horticulture, ARO, The Volcani Center, Bet Dagan 50250 Israel}

Additional index words. ammonium, cut-flower, nitrate, nitrogen

\begin{abstract}
The form of $\mathrm{N}$ supplied to the plant $\left(\mathrm{NH}_{4}^{+}\right.$or $\left.\mathrm{NO}_{3}^{-}\right)$affects growth, morphology and a range of physiological processes in the plant. Little information is available concerning the effects of $\mathbf{N}$ form on development, production or quality of cut-flowers. The present study investigated for the first time the effects of $\mathbf{N}$ form and quantity on growth, flower production and flower quality of Ranunculus asiaticus $\mathbf{L}$. The plants were cultivated in an inert mineral soilless medium (perlite) and were exposed to two levels of nitrogen fertilization $(50$ or $100 \mathrm{ppm})$ and three levels of $\mathrm{NH}_{4}^{+}(10 \%, 20 \%$, or $30 \%$, under $100 \mathrm{ppm}$ nitrogen fertilization). Larger shoots and increased shoot/root ratios were obtained in the lowest $(50 \mathrm{ppm}) \mathrm{N}$ treatment. This treatment also excelled in flower yield production, resulting in higher numbers of total flower produced as well as higher numbers of long flowers. The results demonstrate an effect of $\mathbf{N}$ ferlilization treatments on cut-flower quality. Flowers grown under $50 \mathrm{ppm} \mathrm{N}$ application characterized by almost double vase life duration compared to flowers grown under the various $100 \mathrm{ppm} \mathbf{N}$ treatments. However, flower quantity and quality were not affected by the level of $\mathrm{NH}_{4}$ applied. The $\mathrm{R}$. asiaticus $\mathrm{L}$. root was less sensitive to the $\mathbf{N}$ fertilization treatments than its shoot. Contents of organic $\mathrm{N}, \mathrm{NO}_{3}^{-}, \mathrm{P}, \mathrm{K}$, $\mathrm{Ca}, \mathrm{Mg}, \mathrm{Na}, \mathrm{Cl}, \mathrm{Fe}, \mathrm{Cu}, \mathrm{Zn}, \mathrm{B}$, and $\mathrm{Mo}$ in the leaves were not affected by the fertilization treatments. Taken together, our results suggest a low requirement of $R$. asiaticus $\mathrm{L}$. for $\mathrm{N}$ fertilization, and insensitivity to ammonium concentrations in the range of 10 to $30 \mathrm{ppm}$, $10 \%$ to $30 \%$ of the total $N$ supplied. Detrimental effects in terms of growth, production and cut flower quality were apparent already under 100 ppm $\mathrm{N}$ supply.
\end{abstract}

Nitrogen $(\mathrm{N})$ is one of the most important macronutrients needed by plants (Marschner, 1995). The two major $\mathrm{N}$ sources taken up and metabolized by plants are nitrate $\left(\mathrm{NO}_{3}^{-}\right)$and ammonium ions $\left(\mathrm{NH}_{4}^{+}\right)$. The $\mathrm{N}$ source supplied to the plant affects growth and morphological development (Gerendás et al., 1997), as well as numerous physiological processes such as photosynthesis (Shelp and Taylor, 1990), root respiration (Matsumoto and Tamura, 1981), water relations and uptake (Guo et al., 2002; Ra-

Received for publication 20 Jan. 2005. Accepted for publication 8 Apr. 2005. Contribution of the ARO, The Volcani Center, no. 619/04. The project was supported by the Chief Scientist Fund of the Ministry of Agriculture and the Flower Board in Israel, project No 306 0487-03. We thank David Shmuel and Liana Ben Yunes for skilled technical assistance, and Yael Skotelsky for advice concerning plant protection issues.

${ }^{1}$ To whom reprint requests should be addressed; e-mail Nirit@agri.gov.il. al., 1997) and risosphere $\mathrm{pH}$. Most plants can use either or both ammonium and nitrate, and the effects of the applied $\mathrm{N}$ form depend on the ontogenic development of the plant, the plant species (Claussen and Lenz, 1999) and the supplied concentration of $\mathrm{N}$.

While $\mathrm{N}$ nutrition is well known to affect a range of physiological processes that might affectflower quality, directreports on its effects on cutflower quality are rare. However, N nutrition affects various factors which may influence cut flower quality, such as: osmoregulation (Salsac et al., 1987; Smirnof and Stewart, 1985), water content in the plant (Gerendás et al., 1997), leaf water potential(Adler et al., 1996; Quebedeaux and Ozbun, 1973), accumulation of sugars and organic acids (Chaillou et al., 1991; GanmoreNewmann and Kafkafi, 1983, 1985), low molecular weight, soluble nitrogen compounds such as amino acids or amides (Harada et al., 1968), carboxylates (Jungk, 1967), chlorophyll content (Gerendás et al., 1997), ion uptake into the plants (Bar et al., 1997) and secondary metabolism (Wang and Below, 1996). Therefore, it is reasonable to assume that the supplied $\mathrm{N}$ form exerts considerable influence on cutflower quality as well.

In the present study we aimed to investigate the effects of $\mathrm{N}$ form and $\mathrm{N}$ quantity on the development of Ranunculus asiaticus plants, with a special emphasis on cut flower production and quality.

Ranunculus are perennial plants from the family Ranuncululaceae, native to the Mediterranean basin and Asia Minor. R. asiaticus L., also known as the turban buttercup is the only Ranunculus species cultivated for its ornamental attributes. Because of its long flowering stems and good vase life it is also widely used as a cut flower (Meynet, 1993). In the present study we have examined the effects of three levels of ammonium $(10 \%$, $20 \%$, and $30 \%$, under $100 \mathrm{ppm}$ total $\mathrm{N}$ application) and two levels of N (50 and 100 ppm, under $20 \%$ ammonium application) on growth, production and cut flower quality of greenhouse grown $R$. asiaticus cultivated in perlite, a soilless culture.

\section{Materials and Methods}

and secondary metabolism (Wang and Below, 1996). Additionally, the form of $\mathrm{N}$ supplied to the plant has a strong and inverse effect on uptake of other cations and anions (Pill and Lambeth, 1977; Wilcox et al., 1977), $\mathrm{pH}$ regulation in the cytoplasm (Kosegarten et

Table 1. Details of the $\mathrm{N}$ fertilization treatments applied in the project. Peccent $\mathrm{N}-\mathrm{P}-\mathrm{K}$. fertilizers and the specific weight of the liquid fertilizers are detailed below the chemical formula; SW $=$ specific weight.

\begin{tabular}{|c|c|c|c|c|}
\hline & \multicolumn{4}{|c|}{ Treatment } \\
\hline & $\mathrm{A}$ & B & $\mathrm{C}$ & $\mathrm{D}$ \\
\hline & \multicolumn{4}{|c|}{ ppm N } \\
\hline & 100 & 100 & 100 & 50 \\
\hline & \multicolumn{4}{|c|}{$\% \mathrm{NH}_{4}$} \\
\hline Fertilizer applied ( $\mathrm{g}$ or $\mathrm{cm}^{3}$ commercial product $/ \mathrm{m}^{3}$ irrigation solution) & 30 & 10 & 20 & 20 \\
\hline $\mathrm{NH}_{4} \mathrm{NO}_{3}\left(\mathrm{~cm}^{3} \cdot \mathrm{m}^{-3}\right) 10.5 \% \mathrm{~N}^{-N_{4}}, 10.5 \% \mathrm{~N}_{4} \mathrm{NO}_{3} ; \mathrm{SW}=1.27 \mathrm{~g} \cdot \mathrm{cm}^{-3}$ & 80 & 150 & 80 & 200 \\
\hline $\mathrm{H}_{3} \mathrm{PO}_{4}\left(\mathrm{~cm}^{3} \cdot \mathrm{m}^{-3}\right) 27 \% \mathrm{P} ; \mathrm{SW}=1.68 \mathrm{~g} \cdot \mathrm{cm}^{-3}$ & 50 & 50 & 50 & 50 \\
\hline $\mathrm{HNO}_{3}\left(\mathrm{~cm}^{3} \cdot \mathrm{m}^{-3}\right) 13 \% \mathrm{~N}-\mathrm{NO}_{3} ; \mathrm{SW}=1.3 \mathrm{~g} \cdot \mathrm{cm}^{-3}$ & --- & 100 & 50 & --- \\
\hline $\mathrm{KNO}_{3}\left(\mathrm{~g} \cdot \mathrm{m}^{-3}\right) 13 \% \mathrm{~N}-\mathrm{NO}_{3}, 38 \% \mathrm{~K}$ & 250 & 350 & 350 & 350 \\
\hline $\mathrm{KCl}\left(\mathrm{g} \cdot \mathrm{m}^{-3}\right) 47 \% \mathrm{~K}$ & 100 & --- & --- & --- \\
\hline Urea $\left(\mathrm{g} \cdot \mathrm{m}^{-3}\right) 46 \% \mathrm{~N}-\mathrm{NH}_{2}$ & -- & --- & 50 & --- \\
\hline
\end{tabular}


during the period of October 2003 to March 2004. The greenhouse was covered with a screen (30\% shade), which was replaced with plastic on 10 Nov. 2003.
The cultivar used was 'White Friandin'. The plants were grown in perlite beds, $40 \mathrm{~cm}$ width $\times 20 \mathrm{~cm}$ height, 20 plants per running meter. Forced bulbs (3 weeks in wet vermiculite at $4{ }^{\circ} \mathrm{C}$, followed by 1 week at $\left.9^{\circ} \mathrm{C}\right) 4$ to $5 \mathrm{~cm}$ in diameter, were planted $20 \mathrm{~cm}$ apart along each row, four rows per bed. The experiment had a random block design, with five replicated

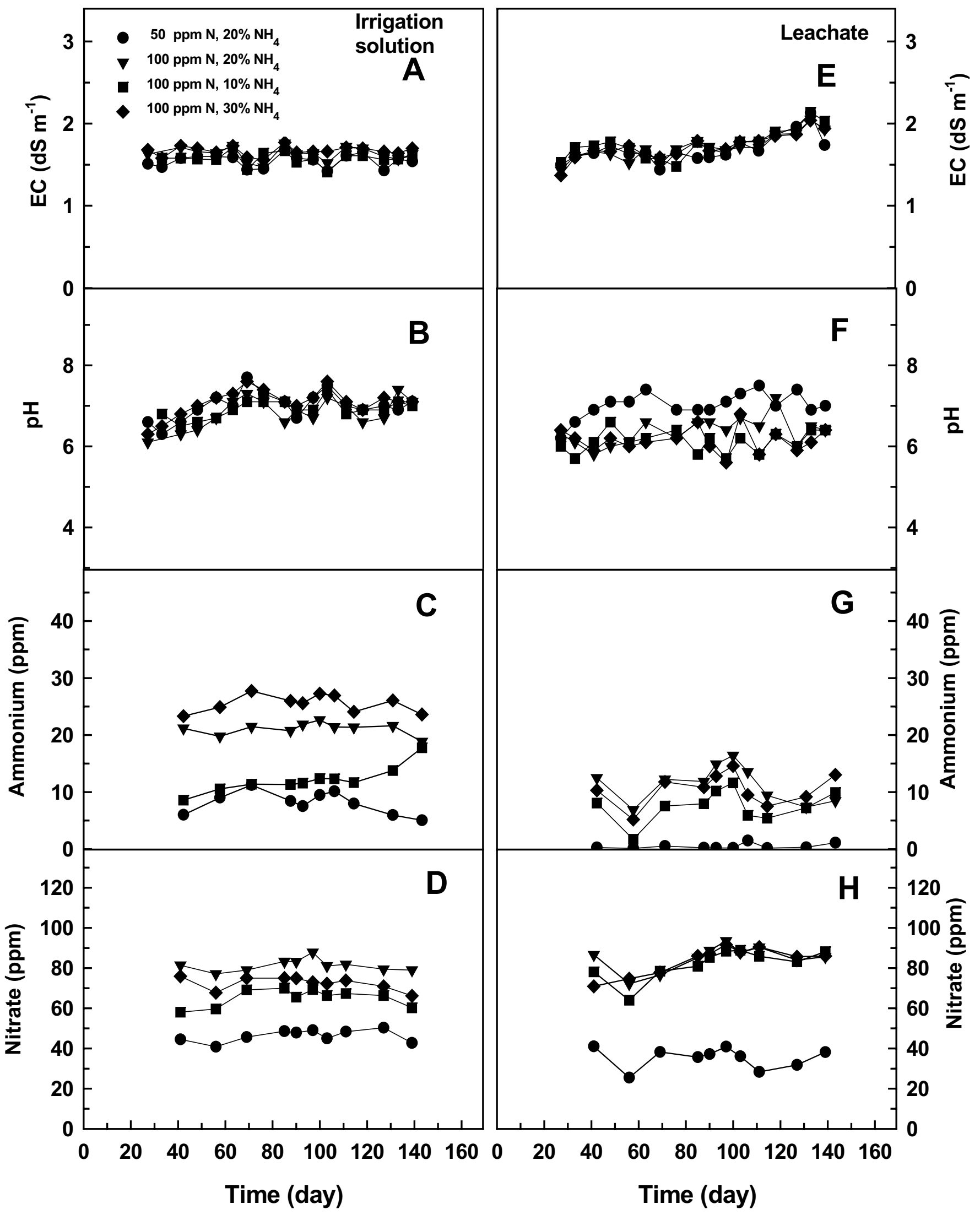

Fig 1. Changes in EC (A and $\mathbf{E})$ and $\mathrm{pH}(\mathbf{B}$ and $\mathbf{F})$ values, ammonium $(\mathbf{C}$ and $\mathbf{G})$ and nitrate $(\mathbf{D}$ and $\mathbf{H})$ concentrations in the irrigation solution $(\mathbf{A}-\mathbf{D})$, and the leachate $(\mathbf{E}-\mathbf{H})$ throughout the experiment. 
plots (4.7 m length each; 94 plants per plot) per treatment. Irrigation was supplied 2 to 4 times a day via $1.6 \mathrm{~L} \cdot \mathrm{h}^{-1}$ discharge-regulated, no-leakage drippers, two laterals per bed, one lateral per row. The volume of irrigation in each irrigation pulse was set to allow at least $25 \%$ to $35 \%$ of leachate in an open system.

Nitrogen fertilization treatments. Four nitrogen fertilization treatments were examined. The four treatments (detailed in Table 1) included two $\mathrm{N}$ level comparisons (50 or $100 \mathrm{ppm} \mathrm{N}$ ), and three $\mathrm{NH}_{4}$ level comparisons $\left(10 \%, 20 \%\right.$, and $30 \% \mathrm{NH}_{4}$, at total $100 \mathrm{ppm} \mathrm{N}$ fertilization). The remaining $\mathrm{N}$ was supplied as $\mathrm{NO}_{3}$ (in the $20 \%$ and $30 \%$ ammonium treatments), or part $\mathrm{NO}_{3}$ and part urea $(65 \%$ and $25 \%$, respectively, in the $10 \%$ $\mathrm{NH}_{4}$ treatment). The $\mathrm{N}$ levels and percentages of $\mathrm{NH}_{4}$ were selected based on growers and agricultural consultants experience with the crop. The nutrient solutions were prepared from commercial fertilizers $\left(\mathrm{NH}_{4} \mathrm{NO}_{3}, \mathrm{KNO}_{3}\right.$,
$\mathrm{KCl}, \mathrm{H}_{3} \mathrm{PO}_{4}, \mathrm{HNO}_{3}$ and Urea; Table 1), and tap water. Similar phosphorous and $\mathrm{K}$ concentrations $\left(22 \mathrm{P}-135 \mathrm{~K}\right.$ in $\left.\mathrm{mg} \cdot \mathrm{L}^{-1}\right)$ were applied to all treatments. The micro-element concentration $\left(\mathrm{mg} \cdot \mathrm{L}^{-1}\right)$ applied to all the treatments were Fe, 1; Mn, 0.5; Zn, 0.25; Cu, 0.04; and Mo, 0.027. All were EDTA-based, and applied as the commercial fertilizer Koratin (Fertilizers and Chemicals Ltd., Israel).

Routine monitoring and measurements. Throughout the experiment, $\mathrm{pH}, \mathrm{EC}$, and $\mathrm{Cl}$ in the leachate and the irrigation solution were monitored daily; $\mathrm{Na}, \mathrm{K}, \mathrm{N}-\mathrm{NO}_{3}, \mathrm{~N}_{-} \mathrm{NH}_{4}, \mathrm{Ca}$, $\mathrm{Mg}$, and $\mathrm{P}$ were analyzed every week; and $\mathrm{B}$, $\mathrm{Mn}, \mathrm{Cu}, \mathrm{Zn}, \mathrm{Al}$, and $\mathrm{Fe}$ were analyzed once a month. Twice during the experiment total $\mathrm{N}$ and $\mathrm{N}-\mathrm{NO}_{2}$ concentrations were also analyzed, and amide concentrations were calculated.

For leaf mineral analyses, the youngest mature leaves on the plant, present not on flowering stems, were sampled $141 \mathrm{~d}$ after planting. Leaves from seven plants were combined for

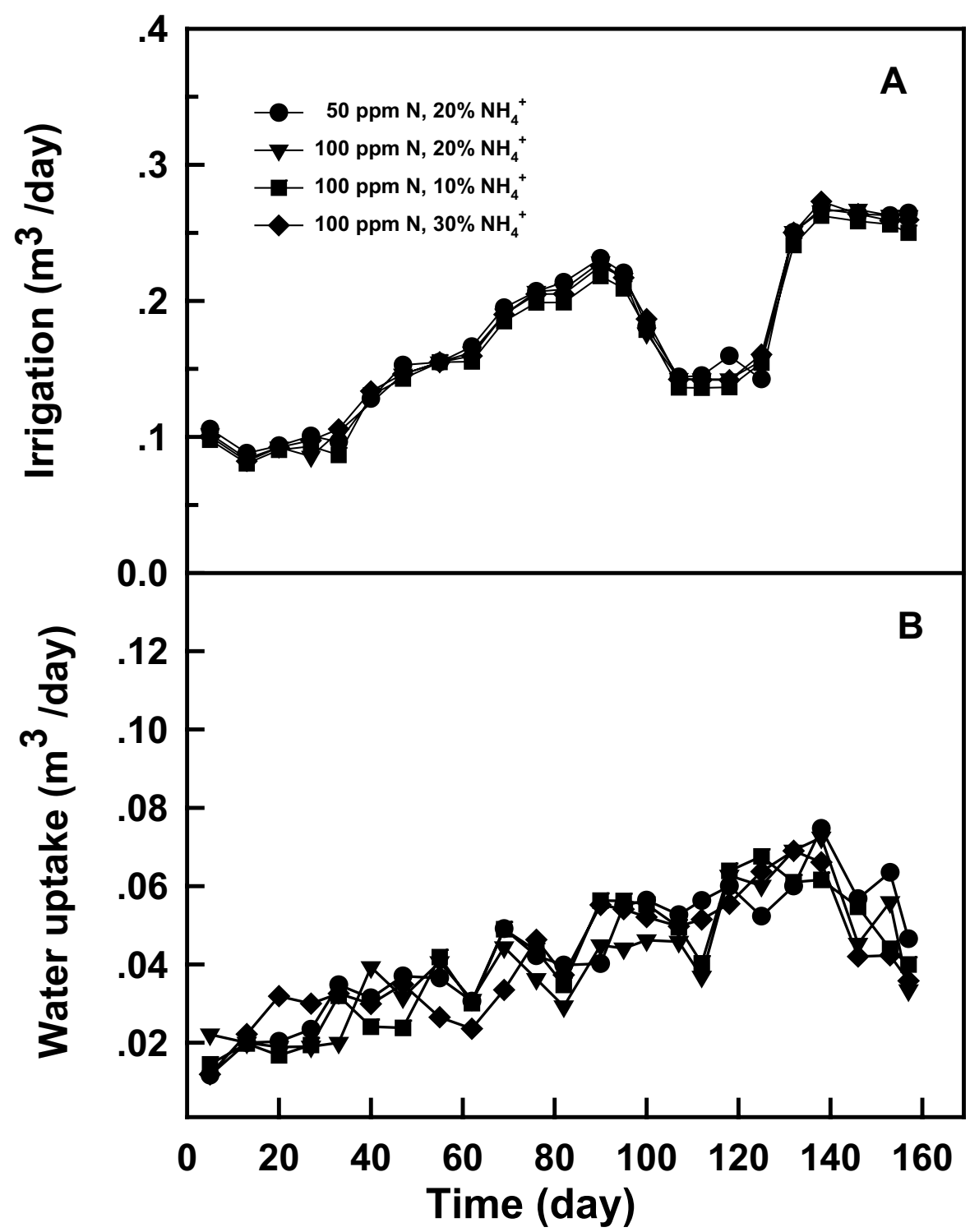

Fig 2. Volumes of water supplied by irrigation (A) and the amount of water taken up by the plants, (B) throughout the growing season. The volume of water taken up by the plants was calculated as the difference between the volume of the irrigation solution supplied and the volume of the leachate. Data points are weekly averages \pm SE of daily measurements. Where not seen, error bars are smaller than the symbol size. each plot sample. Five replicated plots were analyzed per treatment. Results are presented as means $\pm \mathrm{SE}$.

Throughout the experiment, flowers were harvested daily at the closed stage accepted for agronomic picking and the number of flowers per plot was recorded. The flowers in each replicated plot were divided according to their stem length into seven groups $(<25$, 25 to 30,30 to 35,35 to 40,40 to 45,45 to 50 , and $>50 \mathrm{~cm}$ ) and the cumulative weight of flowers in each group was recorded. Mean flower weight for each stem length group was calculated by dividing the group weight by the number of flowers. Flower bud diameter was also recorded at the opening stage recommended for agronomic picking (closed buds). Flowers were harvested throughout the flowering period (days 70 to 150 from planting), in parallel to the routine applied in production fields.

Shoot and root biomass was measured on 3 Oct. 2004, $141 \mathrm{~d}$ after planting, towards the end of the flowering period before the initiation of leaf senescence or bulb development, when plant size was maximal. Biomass from seven plants was combined for each plot sample. Five replicated plots were analyzed per treatment. Results are presented as means $\pm \mathrm{SE}$.

Evaluation of cutflower postharvest quality. Freshly cut flowers with 30-cm-long stems (50 flowers from each treatment) were harvested on 2 Nov. 2004, 112 d after planting, at two opening stages of bud development (close and open), and were brought to the laboratory in water. The cut stem ends were trimmed at the base by $2 \mathrm{~cm}$, and were placed in 1-L glass cylinders ( 10 flowers per cylinder), each containing 500 ml of TOG- 6 solution (Milchan Bros Ltd., Ramat-Gan, Israel) as a bactericide, composed of $5 \mathrm{mg} \cdot \mathrm{mL}^{-1}$ active chlorine complexed as sodium dichloroisocyanureate. The flower cylinders were kept for vase life evaluation in a conditioned standard observation room maintained at $20{ }^{\circ} \mathrm{C}$ with $60 \%$ to $70 \% \mathrm{RH}$ and 12-h photoperiod at a light intensity of 14 $\mu \mathrm{mol} \cdot \mathrm{m}^{-2} \cdot \mathrm{s}^{-1}$, provided by cool-white fluorescent tubes. Flowers were discarded based on leaf yellowing, flower senescence or wilting and stem topple, and their longevity in vase life was determined.

Chemical analyses. The $\mathrm{pH}$ value of the irrigation solution and the leachate was measured with a $\mathrm{pH}$ meter, EC with a conductivity meter, $\mathrm{Na}$ and $\mathrm{K}$ with a flame photometer, $\mathrm{Ca}$ and $\mathrm{Mg}$ with an atomic absorption spectrophotometer. $\mathrm{N}-\mathrm{NH}_{4}, \mathrm{~N}-\mathrm{NO}_{3}, \mathrm{~N}-\mathrm{NO}_{2}, \mathrm{P}, \mathrm{Cl}$, and $\mathrm{SO}_{4}$ were measured using an autoanalyzer (Quickchem 8000, Lachat Instruments, Milwaukee, WI); $\mathrm{Mn}, \mathrm{Cu}, \mathrm{Zn}, \mathrm{Fe}$, and $\mathrm{B}$ by ICP, and total $\mathrm{N}$ by TOC-TN analyzer (Skalar, Breda, The Netherlands). Amide concentration in the irrigation solution and the leachate was calculated as $\left[\right.$ Total N- $\left.\left(\mathrm{NH}_{4}^{+}+\mathrm{NO}_{3}^{-}+\mathrm{NO}_{2}^{-}\right)\right]$.

Three different procedures were applied for extraction of the various mineral elements from the plant tissue. For the analyses of $\mathrm{Cl}$ and $\mathrm{NO}_{3}{ }^{-}$dried plant samples were extracted with water. $\mathrm{Cl}$ was measured with a Chloride meter (PCLM3, Jenway), and nitrate with RQFLEX (N-test, Merck). For the analysis 
of $\mathrm{K}, \mathrm{Na}, \mathrm{Ca}, \mathrm{Mg}, \mathrm{Fe}, \mathrm{Zn}, \mathrm{Mn}, \mathrm{Cu}, \mathrm{Mo}$, and $\mathrm{B}$, the tissue was digested with $\mathrm{HNO}_{3}(65 \%)$ and $\mathrm{HClO}_{4}(70 \%)$. Potassium and $\mathrm{Na}$ were measured by flame photometry, $\mathrm{Ca}$ and $\mathrm{Mg}$ by an atomic absorption spectrophotometer (Perkin Elmer 460), and microelements by Spectroflame Modula ICP(61E Trace analyzer, Thermo electron Corp., Massachusetts). For the analysis of $\mathrm{P}$ and organic $\mathrm{N}$, the dry tissue was digested with $\mathrm{H}_{2} \mathrm{SO}_{4}(95 \%$ to $98 \%$ ) and $\mathrm{H}_{2} \mathrm{O}_{2}(30 \%)$ and $\mathrm{P}$ and organic $\mathrm{N}$ were analyzed by an autoanalyzer (Quichcen 8000, Lachat Instruments, Milwaukee, Wis.).

Statistics. The statistical analysis was carried out with the JMP software package, version 5 (SAS 2002, Cary, N.C.). Analysis of variance as well as means and SE of the following parameters were determined: mineral contents of leaves, shoot and root weight, flower yield (number and weight), number of flowers in each length group and bud diameter.

\section{Results}

Chemical composition of the irrigation solution and the leachate. Routine and fastidious chemical monitoring of the input (irrigation solution) and output (leachate) was practiced to ensure stability of the experimental growing system. The EC values of the irrigation solution (Fig. 1A) and the leachate (Fig. 1E) were similar in all treatments throughout the duration of the experiment. The EC value of the leachate was maintained below 2 by increasing the irrigation volume when needed, to prevent salt build-up in the soilless medium. The amounts of water

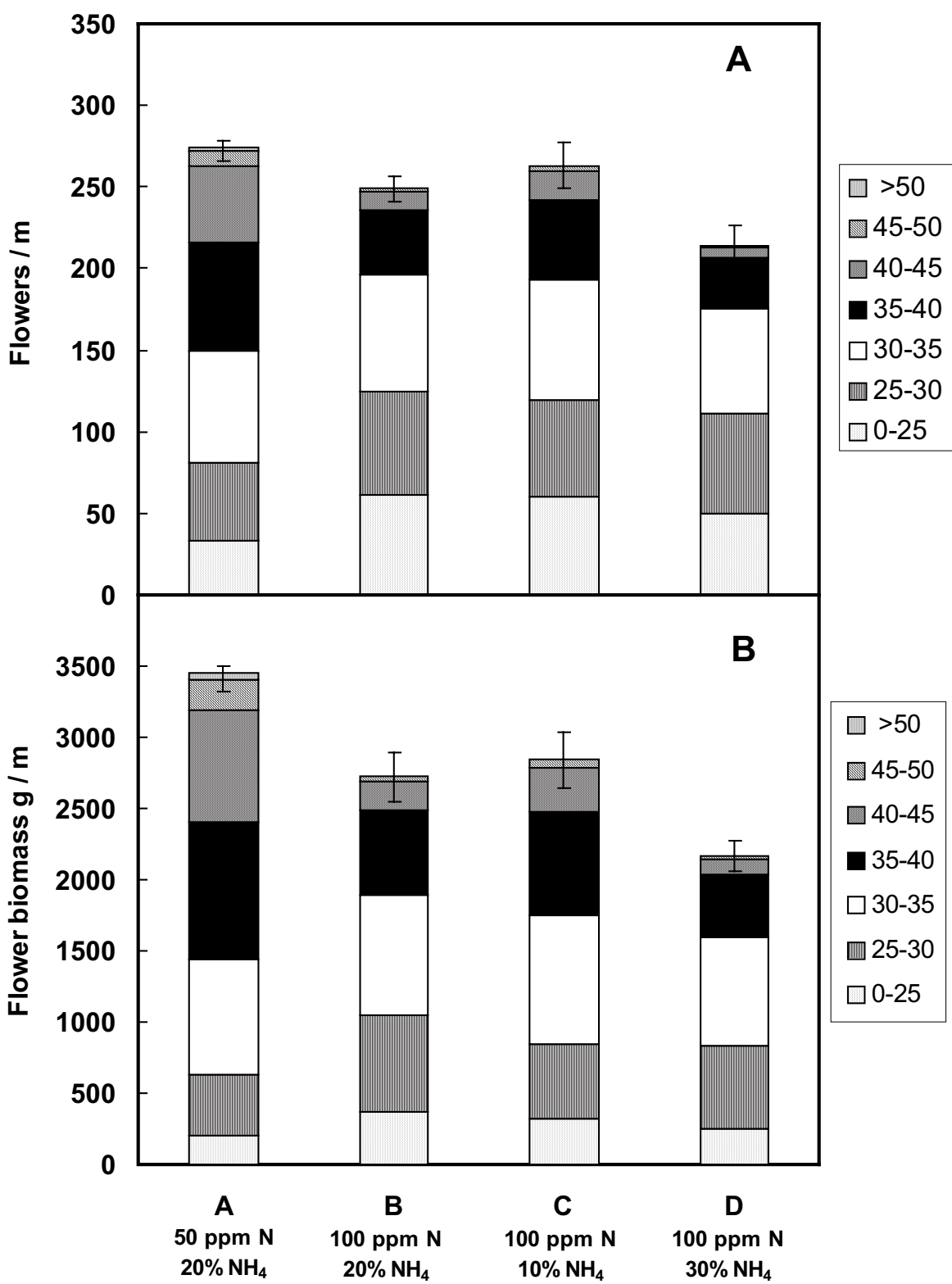

Fig. 3. Effect of nitrogen nutrition on the cumulative number (A) and the biomass (B) of the flowers produced by the plants, and on their distribution according to stem length classes. Results are means \pm SE of five replicated plots per treatment. Data is presented for running $\mathrm{m}$ of growing bed. $P=0.2426$ for the cumulative number of flowers produced; 0.0126 for the number of flowers 0 to $25 \mathrm{~cm}$ long; $<0.001$ for the length classes 35 to $40 \mathrm{~cm}, 40$ to $45 \mathrm{~cm}$ and $45-50 \mathrm{~cm}$, respectively; and 0.0003 for the cumulative biomass of flowers produced. $P$ values for the effect of $\mathrm{NH}_{4}$ under $100 \mathrm{ppm} \mathrm{N}$ application on the number of flowers and the biomass of the flowers are 0.323 and 0.042 , respectively. applied by irrigation throughout the growing season, and the amounts of water taken up by the plants (calculated as volume of irrigation minus volume of the leachate), were similar in all treatments throughout the experiment (Fig. 2A and B).

The $\mathrm{pH}$ values of the irrigation solution (Fig. 1B) and the leachate (Fig. 1F) were steady throughout the growing season (Fig. 1). The $\mathrm{pH}$ of the leachate was lower than that of the irrigation water in all treatments, with the exception of the low $\mathrm{N}$ treatment $(50 \mathrm{ppm} \mathrm{N})$ (Fig. 1B and F).

Ammonium and nitrate concentrations in the irrigation solutions (Fig. 1C and D) and the leachates (Fig. 1G and $\mathrm{H}$ ) were steady throughout the experiment. The concentration ranges for ammonium in the irrigation solutions demonstrate that the target concentrations for the experiment were reached in all treatments, as follows: about $10 \mathrm{ppm}$ in treatments $\mathrm{A}$ and $\mathrm{C}$ (which reflects $20 \%$ of $50 \mathrm{ppm}$ and $10 \%$ of $100 \mathrm{ppm}$, respectively); about $20 \mathrm{ppm}$ in treatment B ( $20 \%$ of $100 \mathrm{ppm})$, and about $30 \mathrm{ppm}$ in treatment $\mathrm{D}$ (30\% of $100 \mathrm{ppm})$. Results of total $\mathrm{N}$ analysis demonstrated that the target concentrations for total $\mathrm{N}$ were reached as well. Total $\mathrm{N}$ concentrations in the irrigation water were $50 \pm 3 \mathrm{ppm}$ in treatment A (the $50 \mathrm{ppm}$ $\mathrm{N}$ treatment), and $100 \pm 8 \mathrm{ppm}$ in treatments $\mathrm{B}, \mathrm{C}$ and $\mathrm{D}$ (the 100 ppm $\mathrm{N}$ treatments).

Except for the $50 \mathrm{ppm} \mathrm{N}$ treatment, where the nitrate concentration in the leachate was lower than in the irrigation water, in all other treatments nitrate concentration was higher in the leachate than in the irrigation solution (Fig. 1D and H). A similar trend was apparent also for total $\mathrm{N}$ (data not shown). Total $\mathrm{N}$ concentrations in the leachate of the $50 \mathrm{ppm} \mathrm{N}$ treatment were $20 \%$ lower than in the irrigation water $(40 \pm 4 \mathrm{ppm})$, while in all the $100 \mathrm{ppm} \mathrm{N}$ treatments it was $15 \%$ higher $(115 \pm 5 \mathrm{ppm})$. This suggests that in the $100 \mathrm{ppm} \mathrm{N}$ treatments, $\mathrm{N}$ supply was excessive, and water uptake was proportionally larger than $\mathrm{N}$ uptake.

Ranunculus asiaticus is very sensitive to a lack of aeration in the growing medium (Meynet, 1993). Twice during the experiment, in December and February, $\mathrm{NO}_{2}{ }^{-}$concentrations in the irrigation solution and the leachate were analyzed. Both measurements showed very low nitrite concentrations $\left(<3 \mathrm{mg} \cdot \mathrm{L}^{-1}\right.$ in the irrigation solution, and $<0.3 \mathrm{mg} \cdot \mathrm{L}^{-1}$ in the leachate) in all treatments, which suggest that proper aeration conditions were maintained in the soilless medium.

$\mathrm{Na}$ concentrations in the irrigation water and the leachate were similar for all treatments and steady over time (data not shown), ranging around 150 and $175 \mathrm{ppm}$, respectively. The $\mathrm{Cl}$ concentrations as well were steady over time in both the irrigation solution and the leachate (data not shown), ranging between 300 and 350 ppm, respectively in treatments $\mathrm{B}, \mathrm{C}$, and $\mathrm{D}$, and about $50 \mathrm{ppm}$ higher in treatment $\mathrm{A}$, due to the application of $\mathrm{KCl}$ (Table 1).

Concentrations of $\mathrm{K}, \mathrm{P}, \mathrm{Ca}$, and $\mathrm{Mg}$ in the irrigation solution and the leachate were similar in all treatments (data not shown), and their concentration in the irrigation solutions were in accordance with the target concentrations 
for the experiment. Microelement concentration in the irrigation water demonstrated as well that the target concentrations for the experiment were reached. Potassium, calcium, and phosphorus concentrations in the leachate were steady throughout the experiment and similar to those of the irrigation solution, suggesting steady requirement throughout the season, and sufficient supply by fertigation. At the same time, $\mathrm{Mg}$ concentration in the leachate increased during the second half of the growing period, suggesting a reduction in $\mathrm{Mg}$ uptake with the progression of the season.

Effect of the fertilization treatments on flower quantity and quality. Although the cumulative number of flowers produced by the plants throughout the season was not significantly affected by the $\mathrm{N}$ fertilization treatments (Fig. 3A), the distribution of flowers to length classes, according to their stem length, was affected. Specifically, fewer short unmarketable flowers, 0 to $25 \mathrm{~cm}$ long, were produced in the $50 \mathrm{ppm} \mathrm{N}$ treatment than in all

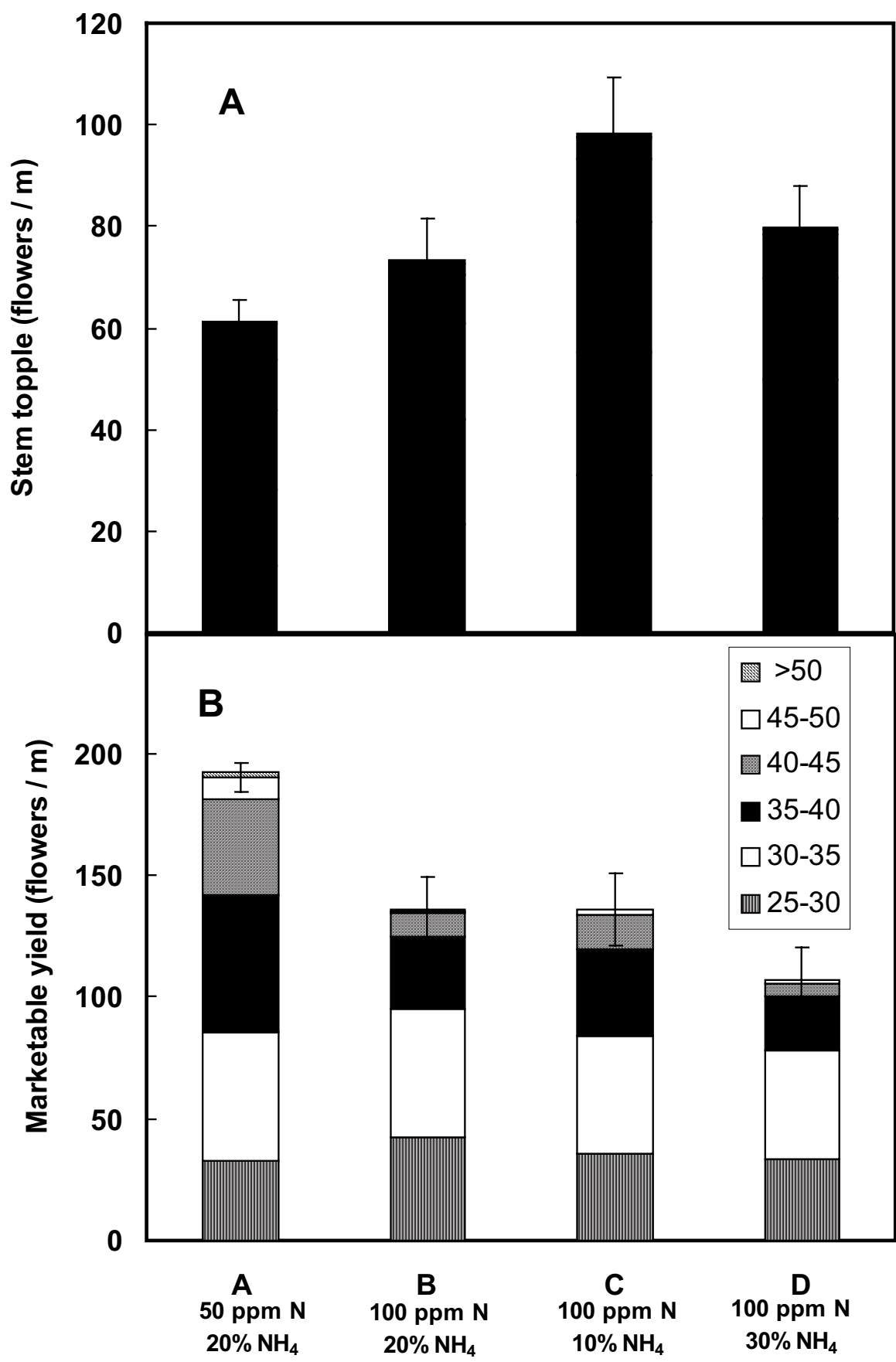

Fig. 4. Effect of nitrogen nutrition on the cumulative number of toppled (A) and marketable (B) flowers produced, and the distribution of the marketable flowers according to stem length classes. Marketable flowers were calculated as flowers $>25 \mathrm{~cm}$, excluding the toppled flowers. Results are means $\pm \mathrm{SE}$ of five replicated plots per treatment. Data is presented for running $\mathrm{m}$ of growing bed. $P=0.048$ for the number of toppled flowers; 0.001 for the cumulative number of marketable flowers; and $<0.0001$ for marketable flowers of the length groups 35 to 40,40 to 45 , and 45 to $50 \mathrm{~cm}$ ). $P$ values for the effect of $\mathrm{NH}_{4}$ under 100 ppm $\mathrm{N}$ application, on toppled flowers and marketable flowers are 0.217 and 0.117 , respectively. other treatments, on account of production of longer, higher quality flowers (Fig. 3A). Consequently, the cumulative biomass of flowers produced under the $50 \mathrm{ppm} \mathrm{N}$ treatment was higher than in all other $\mathrm{N}$ treatments (Fig. 3B). The percentage of ammonium in the fertigation solution did not affect the number of flowers produced but the total biomass of the flowers was lower under $30 \% \mathrm{NH}_{4}$ than $10 \%$ and $20 \%$ $\mathrm{NH}_{4}$ (under 100 ppm N application).

Stem bending and topple is known to be a prevalent problem in some geophytes production systems (Nelson and Niedziela, 1998; Le Nard and de Hertogh, 1993). In the present project, the number of toppled flowers was lowest in the low $\mathrm{N}$ treatment (50 ppm N, Fig. 4A). The percentage of ammonium in the fertigation solution, under $100 \mathrm{ppm}$ $\mathrm{N}$ application, did not affect the number of toppled or marketable flowers. Stem topple occurred in similar proportions in flowers of all length groups (data not shown). The cumulative number of marketable flowers, was highest in the low $\mathrm{N}(50 \mathrm{ppm})$ treatment, as was the number of long marketable flowers in the 35 to 40,40 to 45 , and 45 to $50 \mathrm{~cm}$ length groups (Fig. 4B).

Flower-bud diameter (which determines the diameter of the open flower) is an important quality parameter of cut flowers in general and also of $R$. asiaticus. The amount of $\mathrm{N}$ applied had a significant effect on bud diameter. Thus, plants supplied with 50 ppm $\mathrm{N}$ developed wider flower buds than plants grown under 100 ppm $\mathrm{N}$ application (Table 2). Under uniform total $\mathrm{N}$ supply (100 ppm), the percent of ammonium in the irrigation solution, did not affect the diameter of the flower bud.

When the effect of the $\mathrm{N}$ fertilization treatments on shoot and root biomass was examined (Table 3), the largest shoots were found to develop under the lowest $\mathrm{N}$ fertilization application. Shoot to root ratio as well was highest under $50 \mathrm{ppm} \mathrm{N}$ application (Table 3). Root biomass production and the percentage of DW in shoots and roots were unaffected by the $\mathrm{N}$ fertilization treatments (Table 3).

Effect offertilization treatments on the postharvest quality of cut flowers. The fertilization treatments had a significant effect on vase life duration of the cut flowers, regardless of their opening stage at harvest (Table 4). Thus, the lowest $\mathrm{N}$ treatment (50 ppm) containing $20 \%$ ammonium significantly increased flower vase life compared to the other three fertilizations treatments, but it also increased the percentage of flowers with leaf yellowing (Table 4). The lowest percentage of leaf yellowing was obtained under the highest $\mathrm{N}$ and ammonium concentrations (100 ppm and 30\%, respectively). No interaction between fertilization treatments and flower opening stage at harvest was obtained (Table 4).

For marketing, picking at the closest stage of bud opening is advantageous. Vase life was found not to be affected by the opening stage at picking (Table 4), suggests that the closed stage is appropriate for harvesting in Rannunculus.

Effect offertilization treatments on mineral contents of leaves. The levels of $\mathrm{NO}_{3}^{-}$and 
Table 2. Effect of fertilization treatments on the diameter of the flower bud. Data are means $\pm \mathrm{SE}(\mathrm{n}=5$ plots). Measurements from 100 flowers per plot, per month, were averaged to give the individual plot value. Means within each column, followed by different letters, are significantly different according to Tukey-Kramer test at Alpha $=0.05$.

\begin{tabular}{|c|c|c|c|c|}
\hline \multirow{2}{*}{\multicolumn{3}{|c|}{ Treatment }} & \multicolumn{2}{|c|}{ Bud diam $(\mathrm{mm})$} \\
\hline & & & \multicolumn{2}{|c|}{ Stem length group $(\mathrm{cm})$} \\
\hline No. & ppm N & $\% \mathrm{NH}_{4}^{+}$ & $25-30$ & $35-40$ \\
\hline$\overline{\mathrm{A}}$ & 50 & 20 & $17.80 \pm 0.26 \mathrm{a}$ & $18.63 \pm 0.08 \mathrm{a}$ \\
\hline B & 100 & 20 & $17.34 \pm 0.05 b$ & $17.86 \pm 0.24 b$ \\
\hline $\mathrm{C}$ & 100 & 10 & $17.24 \pm 0.32 b$ & $18.29 \pm 0.16 b$ \\
\hline $\mathrm{D}$ & 100 & 30 & $16.91 \pm 0.21 b$ & $17.39 \pm 0.15 b$ \\
\hline
\end{tabular}

Table 3. Effect of nitrogen nutrition on individual plant shoot and root biomass. Plants were sampled $140 \mathrm{~d}$ after planting, towards the end of the flowering period. Data are expressed on fresh weight (FW), dry weight (DW), and \% DW basis, and represent means \pm SE of five replicates of the biomass excluding the cut flowers. Means within each column, followed by different letters, are significantly different according to Tukey-Kramer test at alpha $=0.05 . P=0.0019$ and 0.00028 for shoot FW and DW; 0.311 and 0.269 for root FW and DW; 0.0019 and 0.00028 for shoot to root ratio on FW or DW basis, respectively.

\begin{tabular}{|c|c|c|c|c|c|c|c|c|c|c|}
\hline \multicolumn{3}{|c|}{ Treatment } & \multicolumn{3}{|c|}{ Shoot } & \multicolumn{3}{|c|}{ Root } & \multicolumn{2}{|c|}{ Shoot:root } \\
\hline No. & ppm N & $\% \mathrm{NH}_{4}^{+}$ & FW (g) & DW (g) & $\% \mathrm{DW}$ & FW (g) & $\mathrm{DW}(\mathrm{g})$ & $\% \mathrm{DW}$ & FW & DW \\
\hline$\overline{\mathrm{A}}$ & 50 & 20 & $163 \mathrm{a} \pm 12$ & $23.1 \mathrm{a} \pm 1.6$ & $14.3 \mathrm{a} \pm 0.5$ & $44.2 \mathrm{ab} \pm 2.3$ & $6.1 \mathrm{a} \pm 0.4$ & $13.7 \mathrm{a} \pm 0.2$ & $3.7 \mathrm{a} \pm 0.3$ & $3.8 \mathrm{a} \pm 0.2$ \\
\hline B & 100 & 20 & $142 a b \pm 2$ & $18.8 \mathrm{~b} \pm 1.9$ & $13.2 \mathrm{a} \pm 0.4$ & $51.2 \mathrm{a} \pm 1.0$ & $6.9 \mathrm{a} \pm 0.2$ & $13.6 \mathrm{a} \pm 0.4$ & $2.8 \mathrm{~b} \pm 0.2$ & $2.7 b \pm 0.3$ \\
\hline $\mathrm{C}$ & 100 & 10 & $116 b \pm 11$ & $15.9 b \pm 1.0$ & $13.9 \mathrm{a} \pm 0.8$ & $47.9 \mathrm{ab} \pm 2.5$ & $7.6 \mathrm{a} \pm 0.3$ & $15.6 \mathrm{a} \pm 0.56$ & $2.4 \mathrm{~b} \pm 0.12$ & $2.1 \mathrm{~b} \pm 0.1$ \\
\hline D & 100 & 30 & $121 \mathrm{~b} \pm 11$ & $18.3 \mathrm{~b} \pm 1.2$ & $15.5 \mathrm{a} \pm 0.5$ & $47.7 \mathrm{ab} \pm 2.0$ & $7.2 \mathrm{a} \pm 0.2$ & $15.2 \mathrm{a} \pm 0.7$ & $2.5 \mathrm{~b} \pm 0.2$ & $2.6 \mathrm{~b} \pm 0.2$ \\
\hline
\end{tabular}

organic $\mathrm{N}$ in the leaves were not affected by the amount of total $\mathrm{N}$ applied or by the percentage of ammonium in the irrigation solution or $(p=0.354)$, (Table 5). Similarly, contents of all other macroelements $(\mathrm{Mg}, \mathrm{Ca}, \mathrm{K}$, and $\mathrm{P})$, microelements ( $\mathrm{Fe}, \mathrm{Mn}, \mathrm{Zn}, \mathrm{Mo}, \mathrm{Cu}$, and $\mathrm{B}$ ), as well as $\mathrm{Na}$ and $\mathrm{Cl}$ were not significantly affected by the nitrogen fertilization treatments (Table 5).

\section{Discussion}

Sensitivity of $R$. asiaticus to ammonium. Many plants do not tolerate high $\mathrm{NH}_{4}^{+}$supply, but the sensitivity to ammonium varies between species (Barker and Mills, 1980). In the present study, $R$. asiaticus was found to be insensitive to ammonium concentration in the range of 10 to $30 \mathrm{ppm}, 10 \%$ to $30 \%$ of the total $\mathrm{N}$ supplied in the irrigation solution (Figs. 3 and 4, Tables 2 and 3 ).

In several studies, the sensitivity to ammo-
Table 4. Effect of nitrogen nutrition on vase life of cut flower and on their leaf yellowing. Leaf yellowing was estimated $6 \mathrm{~d}$ after picking. Means within each column, followed by different letters, are significantly different according to Duncan's multiple range test at $P=0.01$. ${ }^{* * *}$ Significant effects in the two-factor analysis of variance at $P=0.001$. NS Nonsignificant. ND $=$ not determined.

\begin{tabular}{|c|c|c|c|}
\hline \multicolumn{2}{|c|}{$\begin{array}{c}\text { Fertilization } \\
\text { treatments }\end{array}$} & \multirow{2}{*}{$\begin{array}{l}\text { Vase } \\
\text { life } \\
\text { (d) }\end{array}$} & \multirow{2}{*}{$\begin{array}{c}\text { Leaf } \\
\text { yellowing } \\
\text { (\% flowers) }\end{array}$} \\
\hline$\overline{p p m ~ N}$ & $\% \mathrm{NH}_{4}^{+}$ & & \\
\hline$\frac{11}{50}$ & 20 & $11.5 \mathrm{a}$ & 59 \\
\hline 100 & 20 & $6.7 \mathrm{~b}$ & 48 \\
\hline 100 & 10 & $6.8 \mathrm{~b}$ & 54 \\
\hline 100 & 30 & $6.7 \mathrm{~b}$ & 35 \\
\hline \multicolumn{4}{|c|}{ Flower opening stage at harvest } \\
\hline & Closed & $7.6 \mathrm{a}$ & ND \\
\hline & Open & $8.0 \mathrm{a}$ & ND \\
\hline \multicolumn{4}{|c|}{ Two-factor analysis of variance } \\
\hline & ion treatments $(\mathrm{A})$ & **** & ND \\
\hline & opening stage (B) & NS & ND \\
\hline & $\mathrm{A} \times \mathrm{B}$ & NS & ND \\
\hline
\end{tabular}

nium was reported to be related to acidification of the rootzone by ammonium uptake (Maynard and Barker, 1969). Under our experimental setup, $\mathrm{pH}$ of the irrigation solution was similarly

controlled in all treatments (Fig. 1B). While the $\mathrm{pH}$ of the leachate of the $50 \mathrm{ppm} \mathrm{N}$ treatment was maintained close to the irrigation solution value, in all the $100 \mathrm{ppm} \mathrm{N}$ treatments it was

Table 5. Effect of fertilization treatments on contents of inorganic and organic $\mathrm{N}, \mathrm{Na}, \mathrm{Cl}$, micro- and macro-elements in the leaves. Data are means $\pm \mathrm{SE}$ of five replications. The $p$ values for the various elements: $\mathrm{K}=0.758, \mathrm{P}=0.358, \mathrm{Ca}=0.199, \mathrm{Mg}=0.145, \mathrm{Na}=0.597, \mathrm{Cl}=0.326, \mathrm{Fe}=0.4926, \mathrm{Mn}=0.229, \mathrm{Zn}=$ 0.585 and $\mathrm{B}=0.1415$.

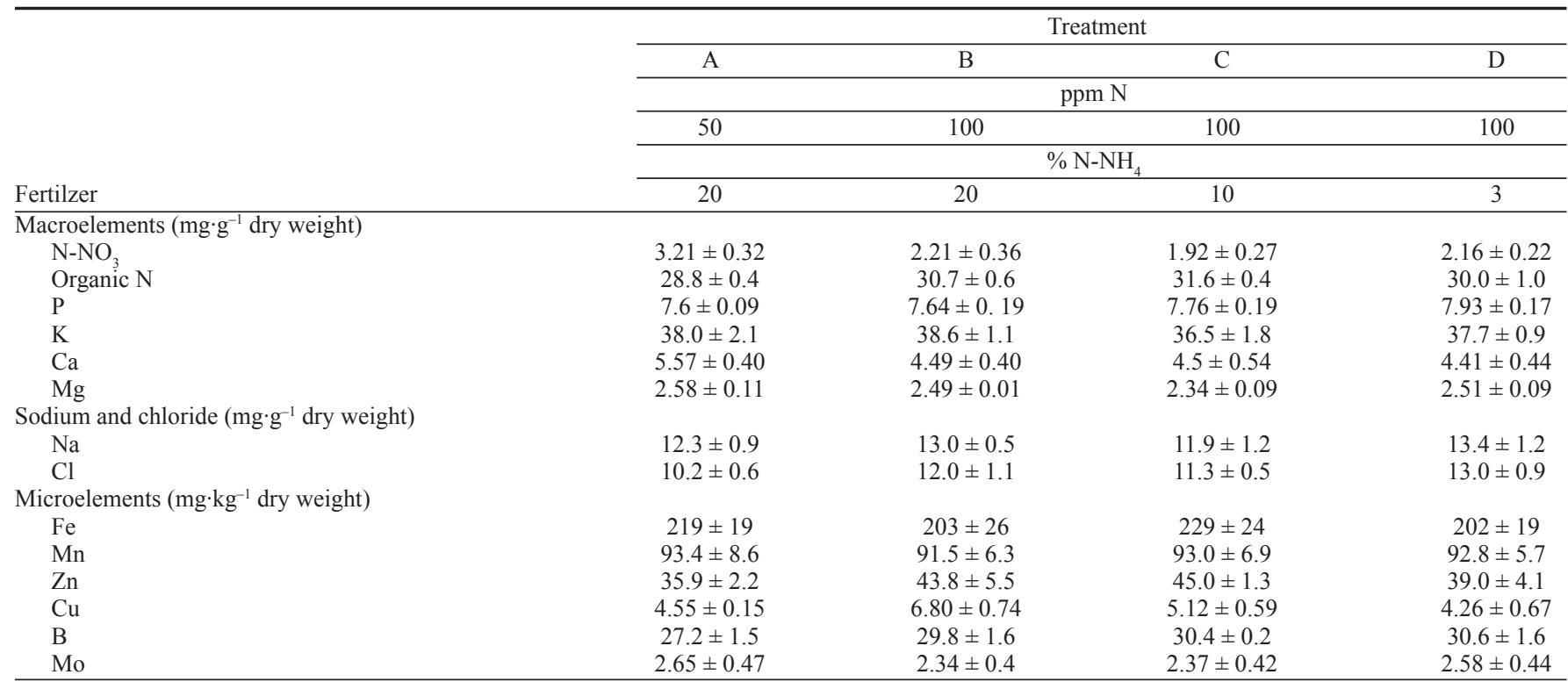


reduced by onepHunit(to pH6)(Fig. 1F). Since $\mathrm{pH} 6$ is considered to be in the optimal range for most plants, and was previously suggested to be within the range tolerated by $R$. asiaticus (Meynet, 1993), it is unlikely that the observed $\mathrm{pH}$ reduction under the $100 \mathrm{ppm} \mathrm{N}$ treatments is the cause of the growth suppression observed under these regimes (Fig. 3B).

The higher $\mathrm{pH}$ value of the leachate obtained in the $50 \mathrm{ppm} \mathrm{N}$ treatment compared to all other treatments can be explained by the differences in the amounts of $\mathrm{N}$ taken up by the plants. In this $\mathrm{N}$ treatment, ammonium, the first form of $\mathrm{N}$ usually taken up by the plants, was completely depleted from the leachate (Fig. 1G), and nitrate concentrations were much reduced (Fig. 1H) as compared to all other treatments. Following depletion of ammonium, the plants took up nitrate. Ammonium uptake is known to induce acidification of the root medium, while nitrate uptake induces alkalinization (Marschner, 1995). Therefore, the higher $\mathrm{pH}$ value of the leachate probably resulted from the higher amounts of nitrate taken up by plants of this treatment. The enhanced demand for total $\mathrm{N}$ in this treatment is probably a direct result from enhanced growth (Table 3, Fig. 3).

$\mathrm{N}$ nutrition is known to affect not only biomass production, but also the partitioning of fixed carbon between shoot and root. High $\mathrm{NH}_{4}^{+}$supply was previously demonstrated to increase shoot to root weight ratio (Cramer and Lewis, 1993; Guo et al., 2002; Raab and Terry, 1994; Walch-Liu et al., 2000). In the present study the shoot/root weight ratio was similar under 10, 20, and $30 \mathrm{ppm} \mathrm{NH}_{4}^{+}$application (and total $\mathrm{N}$ supply of $100 \mathrm{ppm}$ ), but it was increased when the total $\mathrm{N}$ supply was reduced to $50 \mathrm{ppm}$ (Table 3 ). Thus, elevation of the total $\mathrm{N}$ supply from 50 to $100 \mathrm{ppm}$ resulted in a decrease of the shoot/root weight ratio from 3.7 to 2.4 (under 10 ppm $\mathrm{NH}_{4}^{+}$supply; Table 3). This effect on the shoot/root ratio is caused by the reduction of shoot growth under 100 ppm N (Fig. 3). These results demonstrate that the sensitivity of $R$. asiaticus shoot to above-optimal levels of $\mathrm{N}$ is greater than the sensitivity of the root.

Demand of R. asiaticus plants for $N$. Only little is known about the nutritional requirement of $R$. asiaticus for $\mathrm{N}$, or any other nutritional element. Observations in agricultural fields, where different fertigation regimes were applied, suggested that $R$. asiaticus is very responsive to fertigation (G. Luria, Y. Nishri, and N. Umiel unpublished). Additionally, high $\mathrm{N}-\mathrm{P}-\mathrm{K}$ levels obtained in leaf tissues of Rannunculus were previously reported to be positively correlated with high productivity and thick flowering stems, an important parameter for flower quality in $R$. asiaticus (Hassan et al., 1985a). However, several observations in the present study indicate low requirements of $R$. asiaticus for N. First, plant performance in terms of biomass and flower production (Fig. 3 , Table 3), as well as of cut flower longevity in vase life (Table 4), were better under the $50 \mathrm{ppm}$ $\mathrm{N}$ treatment than under the $100 \mathrm{ppm}$ N. Only leaf yellowing in the cut flowers was reduced by the $100 \mathrm{ppm} \mathrm{N}$ treatments, but this may be ascribed to higher ammonium level (Table 4).
Higher productivity under low fertilization was reported also by Hassan et al. (1985b). Second, preliminary study with $150 \mathrm{ppm} \mathrm{N}$ application suggested even greater restriction in growth than under the $100 \mathrm{ppm} \mathrm{N}$ (data not shown). Third, nitrogen concentration in the leachate of the $100 \mathrm{ppm} \mathrm{N}$ treatments was higher than in the irrigation water of the corresponding treatments (Fig. 1). This suggests that supply of $100 \mathrm{ppm} N$ was excessive. Forth, the level of the organic $\mathrm{N}$ in the leaves (Table 5) was not significantly affected when the $\mathrm{N}$ supply was doubled (from 50 to $100 \mathrm{ppm}$ ). This further suggests that $50 \mathrm{ppm} \mathrm{N}$ is sufficient to satisfy the plant requirements.

Effect of fertilization on stem topple of $R$. asiaticus. Similar to the results reported in the present study for soilless cultivation (Fig. 4), in field production systems of Ranunculus in Israel as well, flower-stem topple is a prevalent problem, which reduced economic yield. The observed damage to the flowering stems, which results in bending (topple) and wilting of the flower, is suggestive of unoptimized nutrition. Specifically, this disorder may implicate $\mathrm{Ca}$ deficiency, or excess of $\mathrm{NH}_{4}^{+}$supply. In another geophyte plant, Tulipa, this phenomenon, named topping, is well documented and is considered to be induced by $\mathrm{Ca}$ deficiency (Le Nard and de Hertogh, 1993; Nelson and Niedziela, 1998). Since high supply of $\mathrm{NH}_{4}^{+}$is known to interfere with Ca uptake into plants (Bar Tal et al., 2001; Marschner, 1995), if the disorder in Ranunculus is related to impaired $\mathrm{Ca}$ nutrition, elevated supply of $\mathrm{NH}_{4}^{+}$might have exacerbated the severity or extent of the symptom. However, in the present study, the extent of stem topple in Ranunculus was not correlated with the level of $\mathrm{NH}_{4}^{+}$supplied to the plants (Fig. 4). Additionally, Ca contents of the leaves were not affected by elevating the supply of $\mathrm{NH}_{4}^{+}$(Table 5). Therefore, there is currently no evidence showing that the stem topple disorder observed in Ranunculus, is induced by similar mechanisms to the 'Topping' disorder in Tulipa.

However, it is interesting that the proportion of toppled flowers was significantly smallest in the $50 \mathrm{ppm} \mathrm{N}$ treatment (Fig. 4A), which had much lower levels of $\mathrm{NH}_{4}^{+}$in the leachate than all other treatments (Fig. 1G). Furthermore, although $\mathrm{Ca}$ content of leaves was similar in all treatments (Table 5), reduced contents of $\mathrm{Ca}$ might have been induced locally in the region of the flower stem sensitive to bending. Localized alterations in tissue $\mathrm{Ca}$ contents were previously demonstrated to occur in plants, and to affect growth or induce typical physiological disorders (Bernstein et al., 1993, 1995; Ho and Adams 1989; Lazof and Bernstein, 1999a; Neves Piestun and Bernstein 2004). Therefore, the role of $\mathrm{NH}_{4}^{+}$and Ca nutrition in flower-stem topple development in Ranunculus cannot be excluded, and should be further explored.

Mineral contents in the plant tissues. Macro- and microelement contents of the diagnostic leaf for Ranunculus (the youngest mature leaf) were similar in all treatments (Table 5), and the levels determined were within the range accepted for optimal growth in most plants (Marschner, 1995). However, mineral contents of growing tissues may differ from mature tissues contents (Bernstein et al., 1995; Lazof and Bernstein, 1999a,b; Neves Piestun and Bernstein, 2004). In the case of $\mathrm{Ca}$, increased nutritional demand for rapid cell enlargement might exceed the supply to growing tissues, and further nutrient dilution might occur by the enhanced water deposition which accompanies volumetric growth. Therefore, further insight into the potential role of altered tissue nutrition in growth restriction under excess $\mathrm{N}$ application, or specific damage symptoms to the growing region of the flower-stem, will require chemical analyses of higher spatial resolution in the plant, e.g. in the growing tissues.

Moreover, differences in transport processes dictates that mineral contents of low transpiring plant organs, such as fruits and flowers, might differ from those of rapidly transpiring leaves. Localized changes in contents of specific nutritional elements might therefore be induced in the flower tissues. Such chemical changes may be involved in alterations of cut flower quality and vase life. Since very little is known about the effect of the mineral status of the flower on its quality after harvest, such kind of investigation is worth pursuing.

In a following publication, we therefore evaluate the effect of $\mathrm{N}$ form and quality on the nutritional status of the flower, and the rapidly expanding tissue of the flower-stem which is susceptible to 'Topping'.

\section{Literature Cited}

Adler, P.R., G.E. Wilcox, and A.H. Markhart, III. 1996. $\mathrm{NH}_{4}^{+}$decreases muskmelon root system hydraulic conductivity. J. Plant Nutr. 19:1395-1403.

Bar, Y., A. Apelbaum, U. Kafkafi, and R. Goren. 1997. Relationship between chloride and nitrate and its effect on growth and mineral composition of avocado and citrus plants. J. Plant Nutr. 20:715-731.

Bar Tal, A., B. Aloni, L. Karni, and R. Rosenberg. 2001. Nitrogen nutrition of greenhouse pepper. II. Effects of nitrogen concentration and $\mathrm{NO}_{3}$ : $\mathrm{NH}_{4}$ ratio on growth, transpiration, and nutrient uptake. Hort Sci. 36:1252-1259.

Barker, A.V. and H.A. Mills. 1980. Ammonium and nitrate nutrition of horticultural crops. Hort. Rev. 2:395-423.

Bernstein, N., A. Läuchli, and W.K. Silk. 1993. Kinematics and dynamics of sorghum (Sorghum bicolor $\mathrm{L}$.) leaf development at various $\mathrm{Na} / \mathrm{Ca}$ salinities. I. Elongation growth. Plant Physiol. 103:1107-1114.

Bernstein, N., W.K. Silk, and A. Läuchli. 1995. Growth and development of sorghum leaves under conditions of $\mathrm{NaCl}$ stress: Possible role of some mineral elements in growth inhibition. Planta 196:699-705.

Chaillou, S., J.K. Vessey, J.F. Morot-Gaudry, C.D. Raper, L.T. Henry, and J.P. Boutin. 1991. Expression of characteristics of ammonium nutrition as affected by $\mathrm{pH}$ of the root medium. J. Expt. Bot. 42:189-196.

Claussen, W. and F. Lenz. 1999. Effect of ammonium or nitrate nutrition on net photosynthesis, growth and activity of the enzymes nitrate reductase and glutamine synthetase in blueberry, raspberry and strawberry. Plant Soil. 208:95-102.

Cramer, M.D. and O.A.M. Lewis. 1993. The influ- 
ence of $\mathrm{NO}_{3}^{-}$and $\mathrm{NH}_{4}^{+}$nutrition on the gas exchange characteristics of the root of wheat (Triticum aestivum) and maize (Zea mays) plants. Ann. Bot. 72:37-46.

Ganmore-Newmann, R. and U. Kafkafi. 1983. The effect of root temperature and Nitrate/ammonium ratio on strawberry plants. I. Growth, flowering and root development. Agron. J. 77:835-840.

Ganmore-Newmann, R., and U. Kafkafi. 1985. The effect of root temperature and Nitrate/ammonium ratio on strawberry plants. II. Nitrogen uptake, mineral ions, and carboxylate concentrations. Agron. J. 77:835-840.

Gerendás, J., Z. Zhu, R. Bendixen, R.G. Ratclife, and B. Sattelmacher. 1997. Physiological and biochemical processes related to ammonium toxicity in higher plants. Zeitschrift für Pflanzenernährung and Bodenkunde 160:239-251.

Guo, S., H. Bruck, and B. Sattelmacher. 2002. Effects of supplied nitrogen form on growth and water uptake of French bean (phaseolus vulgaris L.) plants. Plant Soil 239:267-275.

Harada, T., H. Takaki, and Y. Yamada. 1968. Effect of nitrogen sources on the chemical components of young plants. Soil Sci Plant Anal. 14:47-55.

Hassan H.A., E.A. Agina, E.M. Koriesh, and S.M. Mohamad. 1985a. Physiological studies on Anemona coronaria L. and Ranunculus asiaticus L. 1. Effect of light (intensity and duration). Ann. Agr. Sci.-Moshtohor. 22:571-582.

Hassan, H.A., E.A. Agina, E.M. Koriesh, and S.M. Mohamad. 1985b. Physiological studies on Anemona coronaria L. and Ranunculus asiaticus L. 3. Effect of foliar nutrition and gibberellic acid. Ann. Agr. Sci.-Moshtohor. 22:593-615

Ho, L.C. and P. Adams. 1989. Calcium deficiency: a matter of inadequate transport to rapidly growing organs. Plants Today 2:202-207

Jungk, A. 1967. Einfluß von ammonium and ni- trastickstoff auf das kationen-anionen gleichgewicht in pflanzen and seine beziehung zum ertag. Landw. Foesch. 21:50-63.

Kosegarten, H., F. Grolig, J. Wienke, G. Wilson, and B. Hoffmann. 1997. Differential ammonia-elicited changes of cytosolic $\mathrm{pH}$ in root hair cells of rice and maize as monitored by 2',7' bis-(2 carboxyethyl)-5 (and -6) carboxyfluorescein-fluorescence ratio. Plant Physiol. 113:451-461.

Lazof, D.B. and N. Bernstein. 1999a. The NaClinduced inhibition of shoot growth: The case for disturbed nutrition with special consideration of Calcium nutrition. Adv. Bot. Res. 29:113-189.

Lazof. D.B. and N. Bernstein. 1999b. Effects of salinization on nutrient transport to lettuce leaves: Consideration of leaf developmental stage. New Phytol. 144:85-94.

Le Nard, M. and A. de Hertogh. 1993. Tulipa, p. 617-682 In: A. de Hertogh and M Le Nard (eds.). The physiology of flower bulbs. Elsevier, Amsterdam.

Marschner, H. 1995. Mineral nutrition of higher plants. Academic Press, London.

Matsumoto, H. and K. Tamura. 1981. Respiratory stress in cucumber roots treated with ammonium or nitrate nitrogen. Plant Soil. 60:195-204.

Maynard, D.N. and V. Barker. 1969. Studies on the tolerance of plants to ammonium nutrition. J. Amer. Soc. Hort. Sci. 94:235-239.

Meynet, J. 1993. Ranunculus, p. 603-616. In: A. de Hertogh and M. Le Nard (eds.). The physiology of flower bulbs. Elsevier, Amsterdam,

Nelson, P.W. and C.E. Niedziela. 1998. Effects of calcium source and temperature regime on calcium deficiency during hydroponic forcing of tulip. Sci. Hort. 73:137-150.

Neves Piestun, B.G. and N. Bernstein. 2004. Salinity-induced changes in the nutritional status of expanding cells may impact leaf growth inhibi- tion in maize. Funct. Plant Biol. (in press).

Pill, W. and V.N. Lambeth. 1977. Effects of $\mathrm{NH}_{4}$ and $\mathrm{NO}_{3}$ nutrition with and without $\mathrm{pH}$ adjustment on tomato growth, ion composition and water relations. J. Amer. Soc. Hort. Sci. 102:78-81.

Quebedeaux, Jr., B. and J.L. Ozbun. 1973. Effects of ammonium on water stress, water uptake, and root pressure in Lycopersicon esculentum Mill. Plant Physiol. 52:677-679.

Raab. T.K. and N. Terry. 1994. Nitrogen source regulation of growth and photosynthesis in Beta Vulgaris L. Plant Physiol. 105:1159-1166.

Ragab, S.M. 1980. Water uptake and trans-potential in sunflower roots as influenced by ammonium ions. J. Agr. Sci. 94:145-150.

Salsac, L., S. Chaillou, J.F. Morot-Gaudry, C. Lesaint, and E. Joliet. 1987. Nitrate and ammonium nutrition in plants. Plant Physiol. Biochem. 25:805-812.

Shelp, B.J. and D.C. Taylor. 1990. Carbon and nitrogen partitioning in young nodulated pea wild type and nitrate reductase deficient mutant plants exposed to $\mathrm{NO}_{3}^{-}$or $\mathrm{NH}_{4}^{+}$. Can. J. Bot. 69:1780-1786.

Smirnoff, N. and G.R. Stewart. 1985. Nitrate assimilation and translocation by higher plants: comparative physiology and ecological consequences. Physiol. Plant. 64:133-140.

Walch-Liu, P., G. Neuman, F. Bangerth, and C. Engels. 2000. Rapid effects of nitrogen form on leaf morphogenesis in tobacco. J Expt. Bot. 51:227-237.

Wang, X.T. and F.E., Below. 1996. Cytokinins in enhanced growth and tillering of wheat induced by mixed nitrogen source. Crop-sci. 36:121-126.

Wilcox, G.E., C.A. Mitchel, and J.E. Hoff. 1977. Influence of nitrogen form on exudation rate and ammonium, amide and cation composition of xylem exudates in tomato. J. Amer. Soc. Hort. Sci. 102:492-196. 